\title{
Seismic and geologic controls on spatial clustering of landslides in three large earthquakes
}

\author{
Claire Rault ${ }^{1}$, Alexandra Robert ${ }^{2}$, Odin Marc ${ }^{3}$, Niels Hovius ${ }^{4,5}$, and Patrick Meunier ${ }^{1}$ \\ ${ }^{1}$ Laboratoire de Géologie, UMR 8538, École Normale Supérieure, 75005 Paris, France \\ ${ }^{2}$ Géosciences Environnement Toulouse, Observatoire Midi-Pyrénées, 31400 Toulouse, France \\ ${ }^{3}$ École et Observatoire des Sciences de la Terre - Institut de Physique du Globe de Strasbourg, Centre National \\ de la Recherche Scientifique UMR 7516, University of Strasbourg, 67084 Strasbourg CEDEX, France \\ ${ }^{4}$ Helmholtz Centre Potsdam, German Research Centre for Geosciences (GFZ), Telegrafenberg, \\ 14473 Potsdam, Germany \\ ${ }^{5}$ Institute for Earth and Environmental Sciences, University of 14476 Potsdam, Germany \\ Correspondence: Claire Rault (claire.rault@ens.fr)
}

Received: 9 November 2018 - Discussion started: 26 November 2018

Revised: 22 May 2019 - Accepted: 5 July 2019 - Published: 2 September 2019

\begin{abstract}
The large, shallow earthquakes at Northridge, California (1994), Chi-Chi, Taiwan (1999), and Wenchuan, China (2008), each triggered thousands of landslides. We have determined the position of these landslides along hillslopes, normalizing for statistical bias. The landslide patterns have a co-seismic signature, with clustering at ridge crests and slope toes. A cross-check against rainfall-induced landslide inventories seems to confirm that crest clustering is specific to seismic triggering as observed in previous studies. In our three study areas, the seismic ground motion parameters and lithologic and topographic features used do not seem to exert a primary control on the observed patterns of landslide clustering. However, we show that at the scale of the epicentral area, crest and toe clustering occur in areas with specific geological features. Toe clustering of seismically induced landslides tends to occur along regional major faults. Crest clustering is concentrated at sites where the lithology along hillslopes is approximately uniform, or made of alternating soft and hard strata, and without strong overprint of geological structures. Although earthquake-induced landslides locate higher on hillslopes in a statistically significant way, geological features strongly modulate the landslide position along the hillslopes. As a result the observation of landslide clustering on topographic ridges cannot be used as a definite indicator of the topographic amplification of ground shaking.
\end{abstract}

\section{Introduction}

Seismic ground shaking triggers many landslides in active mountain areas. A growing number of catalogues of landslides associated with large earthquakes is now being produced by mapping from satellite images (Tanyaş et al., 2017; U.S. Geological Survey, 2018b). Such catalogues have been used to show that to the first order, the density of co-seismic landslides is controlled by the intensity of seismic shaking and by hillslope rock strength and that the total volume of landslides and the area extent affected by them increase with the earthquake magnitude (Keefer, 1984; Marc et al., 2016, 2017; Rodríguez et al., 1999).
In recent years, several studies have explored the position of landslides in the landscape, adding this characteristic to their description of landslide inventories. At the catchment scale, landslides triggered by storms and earthquakes affect different parts of ridge-and-valley topography (Densmore and Hovius, 2000; Meunier et al., 2008). Storminduced landslides are preferentially triggered low on slopes due to riverbank erosion and high groundwater pressure (Lin et al., 2011; Meunier et al., 2008; Tseng et al., 2018). By contrast, earthquake-triggered landslides are more uniformly distributed since ground shaking affects all portions of the hillslope (Densmore and Hovius, 2000), or they are concen- 
trated near ridges or slope breaks (Harp and Jibson, 1996; Massey et al., 2017; Sepúlveda et al., 2010; Weissel and Stark, 2001). Numerical simulations of ground shaking in complex topographies predict that seismic waves are actually amplified around ridge crests (e.g. Boore, 1973; Massa et al., 2014; Poursartip et al., 2017). Both seismic noise analysis and strong motion records confirm that stronger shaking often occurs at topographic highs (Chávez-García et al., 1996; Durante et al., 2017; Hartzell et al., 2014; Massa et al., 2010). Meunier et al. (2008) suggested that earthquakeinduced landslides tend to cluster around ridge crests as a consequence of these topographic site effects. Yet, the amplification of ground shaking around the crests predicted by numerical studies is found to be modest, mostly 1.2 to 2.5 times the flat model, depending in particular on the shape of the hill and the seismic wave frequency considered (Ashford et al., 1997; Asimaki and Mohammadi, 2018; ChávezGarcía et al., 1996; Geli et al., 1988; Lovati et al., 2011; Pedersen et al., 1994). Numerous authors have argued that larger crest amplifications observed in the field are mostly caused by lithological contrasts along the wave path and possible upward propagation of Rayleigh waves from the base of a slope towards the crest (Burjánek et al., 2014; Gallipoli et al., 2013; Glinsky and Bertrand, 2017; Havenith et al., 2003; Ohtsuki and Harumi, 1983).

Here, we study the spatial variations of the position of coseismic landslides on hillslopes within the epicentral areas of three large, shallow earthquakes affecting steep mountain topography: the $1994 M_{\mathrm{w}} 6.7$ Northridge earthquake, the $1999 M_{\mathrm{w}} 7.6$ Chi-Chi earthquake, and the $2008 M_{\mathrm{w}} 7.9$ Wenchuan earthquake. We also consider the location of rainfall-triggered landslides in the area affected by the ChiChi earthquake for comparison. Using a statistical approach, we identify coherent patterns of ridge crest and slope toe clustering. We explore seismic, topographic, lithological, and structural features as possible controls on the observed patterns and conclude that co-seismic landslide distributions are best explained by the superposition of the effects of local geological configurations on general seismically controlled patterns.

\section{Study areas and landslide inventories}

We use previously published landslide inventories for three earthquakes (Table 1), constructed by digitizing landslide outlines from field and air photos, as well as satellites images. These inventories have been shown to be relatively complete for landslides larger than $30 \mathrm{~m}^{2}$, but they do not allow for a distinction between the erosional and depositional parts of landslides.

\subsection{The 1994 Northridge earthquake}

The $M_{\mathrm{w}} 6.7$ Northridge earthquake occurred on 17 January 1994, about $100 \mathrm{~km}$ north of Los Angeles in southern California. Rupture started on the Northridge blind-thrust fault at about $19 \mathrm{~km}$ of depth (Somerville et al., 1996). It generated strong ground shaking with peak ground acceleration (PGA) up to $1.78 \mathrm{~g}$. More than 11000 landslides were triggered, with a cumulative area of more than $23 \mathrm{~km}^{2}$ (Harp and Jibson, 1996). Most of these landslides were located in the Santa Susanna and San Gabriel Mountains.

\subsection{The 1999 Chi-Chi earthquake}

On 21 September 1999, the shallow $M_{\mathrm{w}}$ 7.6 Chi-Chi earthquake occurred in the western foothills of Taiwan's Central Range. The rupture initiated along the Chelungpu thrust fault at $12 \pm 5 \mathrm{~km}$ of depth (Angelier et al., 2001). Strong ground shaking was recorded with a PGA up to $1 \mathrm{~g}$ in some places (Tsai and Huang, 2000). The earthquake caused about 10000 landslides with a combined area in excess of $125 \mathrm{~km}^{2}$ (Liao and Lee, 2000).

\subsection{The 2008 Wenchuan earthquake}

On 12 May 2008, the $M_{\mathrm{w}} 7.9$ Wenchuan earthquake occurred along the eastern boundary of the Tibetan Plateau. The rupture initiated at a focal depth of 14 to $19 \mathrm{~km}$ and propagated along two segments of the Longmen Shan thrust system (De Michele et al., 2010; Tong et al., 2010). Strong ground motion was felt with recorded PGA exceeding $0.8 \mathrm{~g}$ in some places (Wen et al., 2010). The earthquake caused a large number of landslides: more than 197000 were mapped, with a cumulative surface area exceeding $700 \mathrm{~km}^{2}$ (Xu et al., 2014). At least three catalogues are available for this earthquake (Gorum et al., 2011; Parker et al., 2011; Xu et al., 2014). Here, we use the one from Xu et al. (2014), which we deem to be the most complete and accurate based on a comparison detailed in the Supplement ("Dependence on the dataset”, Fig. S10).

\subsection{Rainfall-induced landslides in the Chi-Chi epicentral area}

In 2009, typhoon Morakot deposited up to $31.9 \mathrm{~m}$ of rainwater in $48 \mathrm{~h}$ in the considered area (Chien and Kuo, 2011). More than 15000 landslides were triggered by this typhoon (Marc et al., 2018) in an area that extends into the Chi-Chi epicentral area. In the area of overlap, the characteristics of the landslide populations associated with the earthquake and the typhoon can be compared directly. Moreover, we document the time variation of the location of the landslides in three watersheds in the Chi-Chi epicentral area from 1994 to 2014 (Marc et al., 2015, Table 1). The location of these three catchments is reported in Figs. 2 and 3. 
Table 1. Details of the inventories used for earthquake- and rainfall-induced landslides.

\begin{tabular}{|c|c|c|c|c|c|c|c|}
\hline Database & Date & Country & $\begin{array}{r}\text { Number of } \\
\text { landslides }\end{array}$ & $\begin{array}{r}\text { Surface } \\
\text { covered by } \\
\text { landslides } \\
\left(\mathrm{km}^{2}\right)\end{array}$ & Trigger & $\begin{array}{l}\text { Landslide } \\
\text { inventory } \\
\text { origin }\end{array}$ & $\begin{array}{l}\text { Data and } \\
\text { methods } \\
\text { used to } \\
\text { map the } \\
\text { landslides }\end{array}$ \\
\hline Pre-Chi-Chi & 1994-1999 & Taïwan & 375 & 2.7 & Rainfall & Marc et al. (2015) & Satellites images \\
\hline Chi-Chi & 1999 & Taïwan & 9272 & 127.6 & Earthquake & $\begin{array}{l}\text { Liao and Lee } \\
\text { (2000) }\end{array}$ & $\begin{array}{l}\text { Aerial photographs } \\
\text { and satellites images }\end{array}$ \\
\hline Post-Chi-Chi & 1999-2004 & Taïwan & 1647 & 10.1 & Rainfall & Marc et al. (2015) & $\begin{array}{l}\text { Satellites images and } \\
\text { air photos }\end{array}$ \\
\hline Morakot & 2009 & Taïwan & 17344 & 225.0 & Typhoon & Marc et al. (2018) & Satellites images \\
\hline Wenchuan & 2008 & China (Sichuan) & 197481 & 1160 & Earthquake & Xu et al. (2014) & $\begin{array}{l}\text { Aerial photographs } \\
\text { and satellites images }\end{array}$ \\
\hline Northridge & 1999 & USA (California) & 11111 & 25.9 & Earthquake & $\begin{array}{l}\text { Harp and Jibson } \\
\text { (1996) }\end{array}$ & $\begin{array}{l}\text { Air photos and field } \\
\text { observations }\end{array}$ \\
\hline
\end{tabular}

\section{Methods}

\subsection{Landslide position in the landscape}

Our aim is to determine the position of landslides within the landscape, specifically their position relative to a ridge crest or the top of a hillslope and to the river valley or toe of a hillslope. For this, we adopt the metrics of Meunier et al. (2008) to normalize for the variation of hillslope lengths across the landscape, introducing the normalized distance to stream $\left|d_{\text {st }}\right|$. Ridge crests are characterized by a $\left|d_{\text {st }}\right|$ equal to one, while rivers have a $\left|d_{\mathrm{st}}\right|$ equal to zero (see the Supplement, "Methods and metrics").

A given portion of the landscape is characterized by its probability density function of occurrence of $\left|d_{\mathrm{st}}\right|$ values, $\mathrm{PDF}_{\text {topo }}$ (Fig. S1e). Landslide locations are characterized by $\mathrm{PDF}_{\mathrm{ls}}$, the probability density function of $\left|d_{\mathrm{st}}\right|$ derived only from cells affected by landslides. Within portions of the epicentral area (macrocells), we compute both $\mathrm{PDF}_{\text {topo }}$ and $\mathrm{PDF}_{1 \mathrm{~s}}$, and we define the ratio of probability $R_{\mathrm{p}}=$ $\mathrm{PDF}_{\mathrm{ls}} / \mathrm{PDF}_{\text {topo }}$. In this way, the distribution of the locations of the landsliding cells along hillslopes (here expressed in $\left.\left|d_{\text {st }}\right|\right)$ is normalized by the distribution of occurrence of locations in the landscape of the macrocell, effectively removing geomorphic or methodological biases (Fig. S1e, f). If the landscape into the macrocell is uniformly sampled by landsliding, $R_{\mathrm{p}}=1$ over $(0,1)$. High values of $R_{\mathrm{p}}(\gg 1)$ for $\left|d_{\mathrm{st}}\right|>0.75$ indicate a significant crest oversampling by landslides. Inversely, low values of $R_{\mathrm{p}}$ express undersampling. Similarly, large values of $R_{\mathrm{p}}$ for $\left|d_{\mathrm{st}}\right|<0.25$ indicate hillslope toe oversampling. In our analysis, we have defined $R_{\mathrm{p}_{\text {crest }}}=\overline{R_{\mathrm{p}_{[0.75-1)}}}$ and $R_{\mathrm{p}_{\text {toe }}}=\overline{R_{\mathrm{p}_{(0-0.25]}}}$ as the mean value of $R_{\mathrm{p}}$ over the upper and the lower quarter of the hillslope, respectively.

\subsection{Crest and toe clustering}

The purpose of this paper is first to detect if there are areas where landslides are more likely to occur on a given portion of the hillslope (i.e. if crests or toes are more susceptible to fail during an earthquake), and if so, what physical processes could explain it. Macrocells with very few landslides are not statistically representative. Therefore, we must be able to quantify the probability for a given topography and the landslides within it that the observed $R_{\mathrm{p}}$ could differ from one because of statistical fluctuations rather than for physical reasons. To do this, we test the null hypothesis by comparing the $R_{\mathrm{p}}$ derived from the data to one associated with a random sampling of the landscape. In each macrocell, we define the $90 \%$ interval of confidence $I_{\mathrm{rp}}$ depending on the number of landslides affecting it. Crest clustering, defined here as preferential sampling of the upper quarter of a hillslope section by landsliding, is only considered to occur where $R_{\text {prest }_{\text {cre }}}$ exceeds the upper bound of $I_{\mathrm{rp}}$. Similarly, $R_{\mathrm{ptoe}}$ is defined as the average of $R_{\mathrm{p}}$ computed over the lower quarter of the slope, and toe clustering is adjudged for $R_{\text {ptoe }}$ values greater than the upper bound of $I_{\mathrm{rp}}$ (Fig. S2). Since crest clustering and toe clustering are mutually exclusive (see the Supplement, "Statistical robustness", Fig. S4), zones of toe clustering also have values of $R_{\mathrm{p}_{\text {crest }}}$ lower than the lower bound of $I_{\mathrm{rp}}$. Therefore, $R_{\text {prest }}$ can be used as an indicator of crest and toe clustering.

\subsection{Spatial mapping of the landslide position within the epicentral area}

Maps of $R_{\mathrm{p}_{\text {crest }}}$ and $R_{\text {ptoe }}$ were generated by subdividing a study area into macrocells in which $R_{\mathrm{p}}$ is calculated. The size of the macrocells in this study is set at $7.8 \mathrm{~km}^{2}$ to optimize for two criteria: (a) the cell must be small enough to capture the spatial variation within the epicentral area, and (b) it must be large enough to be statistically representative 
in terms of landslide content (see the Supplement, "Methods and metrics"). The second criterion imposes a lower limit to the resolution at which we can observe any spatial variation. Figure S5 shows three $R_{\text {prest }}$ maps in the Wenchuan epicentral area with increasing macrocell size. Although the patterns remain globally the same, macrocells of $7.8 \mathrm{~km}^{2}$ produce the most legible map. The mean of $R_{\text {prest }_{\text {e }}}$, averaged over the whole landscape, remains relatively independent of the macrocell size (Table 2, the Supplement).

\subsection{Extraction of seismic and topographic parameters}

In each macrocell, we compute the median of the seismic parameters according to the USGS ShakeMap (Allen and Wald, 2007; U.S. Geological Survey, 2018a). Shake maps provide the peak ground velocity (PGV), peak ground acceleration (PGA), and the pseudo-spectral acceleration (PSA) in 2015 at 3,1 , and $0.3 \mathrm{~s}$.

Relations have been observed between seismic ground motion and the ridge shape and orientation with respect to the epicentre. For example, the ridge half-width can be related to the frequency of resonance of the topography (e.g. Paolucci, 2002; Massa et al., 2014), and the ridge shape ratio (slope height to ridge width) can be linked to the ground motion amplification (Geli, 1988). To test if the clustering can be associated with the geometry of the ridges we calculate and associate with each macrocell the median slope heights and the median of the ridge half-widths. To do this, we perform a geometric extraction of the ridge relief by simplifying the geometry of the topographic ridge cross section by a triangular shape (see the Supplement, "Extraction of topographic features", Fig. S8).

\subsection{Lithological features}

In order constrain the influence of rock strength on landslide location patterns, we group lithologies that have similar apparent physical properties using the information provided by geological maps of the earthquake epicentral areas (see Fig. S9). For the Northridge area, we use a combination of the maps compiled by the United States Geological Survey (Yerkes et al., 2005; Jennings and Strand, 1969). For Taiwan, we use materials from the Taiwan Central Geological Survey, MOEA (MOEA and Central Geological Survey, 2008), and for Wenchuan we use the map published by Robert (2011). Each macrocell is defined by its dominant lithology group, i.e. the one occupying the largest area.

\section{Results}

\subsection{Temporal variation of crest clustering}

To test if seismic ground shaking and rainstorms cause hillslope failures in different parts of the landscape, we first consider the temporal variation of clustering in the upper quar-

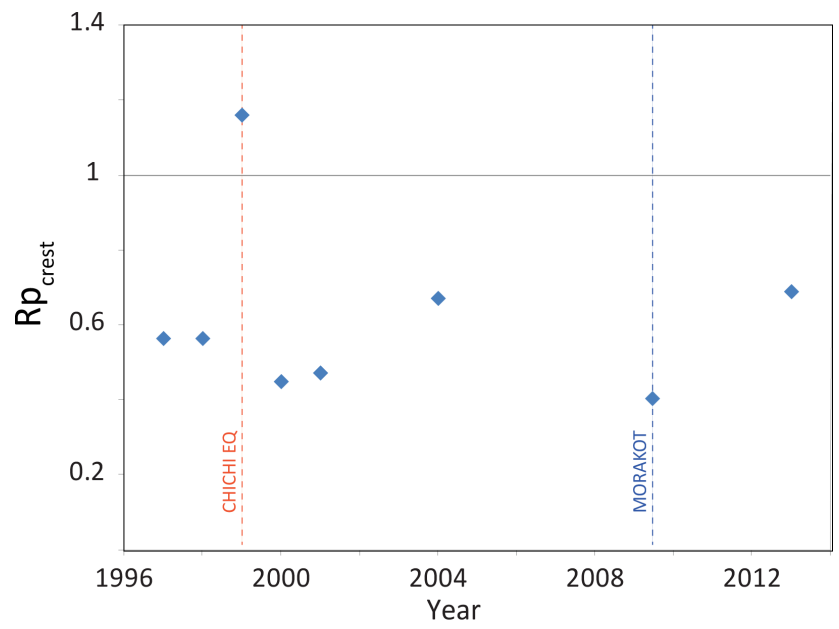

Figure 1. Time variation of the landslide crest clustering $R_{\mathrm{p}_{\text {crest }}}$ in three watersheds in the Chi-Chi epicentral area mapped in Fig. 2. Chi-Chi-induced landslides sit well above the previous and subsequent rainfall-triggered landslides.

tile of slopes in three watersheds in the Chi-Chi epicentral area between 1996 and 2014 (Fig. 1). Before the Chi-Chi earthquake, typhoon-induced landslides tended to undersample the upper slope domain $\left(R_{\mathrm{p}_{\text {crest }}}<0.6\right)$. The Chi-Chi earthquake itself was characterized by clear crest oversampling $\left(R_{\mathrm{p}_{\text {crest }}}=1.2\right)$. Just after the earthquake, $R_{\mathrm{p}_{\text {crest }}}$ dropped to 0.4 and returned to its pre-earthquake value in about 3 years. This evolution seems to confirm that landslides triggered by earthquakes and rainfall have distinct and different clustering behaviour, as observed in previous studies (Meunier et al., 2008; Densmore and Hovius, 2000).

\subsection{Spatial variation of crest clustering}

Figure 2 shows the spatial distribution of $R_{\mathrm{p}_{\text {crest }}}$ in the three epicentral areas. Macrocells without statistically significant clustering are removed for clarity (see the Supplement, "Statistical robustness"). In the three cases, we observe coherent patterns of crest and toe clustering on about half of the surface affected by landsliding (Fig. 2). These patterns can cover several tens of square kilometres, and they have similar sizes in the three epicentral areas. Hence, the larger the epicentral area the more individual patterns we observe. Specifically, the Northridge epicentral area is almost exclusively affected by crest clustering (Fig. 2b). Two coherent zones are observed in the Chi-Chi epicentral area: crest clustering in the western part of the epicentral area and toe clustering in the eastern part (Fig. 2c). In the Wenchuan case, five or six distinct patches of crest clustering can be identified. They are separated by more or less elongated zones of toe clustering extending up to several tens of kilometres (Fig. 2a). Overall, crest clustering does not appear to be a dominant pattern in the Wenchuan case. Note that in the Wenchuan case, the pattern of clustering is very sensitive to the quality of the land- 


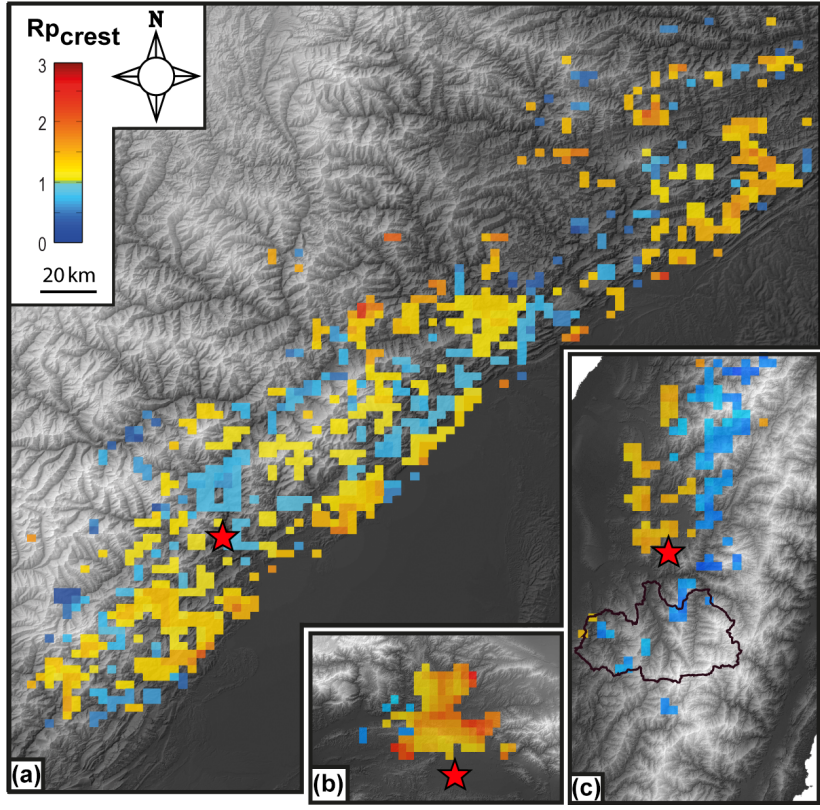

Figure 2. $R_{\text {prest }_{\text {cr }}}$ maps in the (a) Wenchuan, (b) Northridge, and (c) Chi-Chi epicentral area. The three maps are at the same scale. The study areas are divided in macrocells of $7.8 \mathrm{~km}^{2}$. Only cells of $R_{\mathrm{p}_{\text {crest }}}$ above the $90 \%$ prediction interval are represented (see "Methods and metrics"). Regions of crest clustering are coloured in yellow-red. Regions of toe clustering are coloured in blue. Clear coherent patterns of crest and toe clustering are identified. The black curve delimits the three watersheds where $R_{\text {prest }_{\text {cr }}}$ is documented between 1996 and 2014 (Fig. 1).

slide inventory (Fig. S11). In the following, we only consider results obtained with the Xu et al. (2014) dataset. Therefore, the three cases show that earthquake-triggered landslides are distributed quite evenly along many slopes in an epicentral area, with upper slope or slope toe clustering in some places.

The spatial distribution of $R_{\mathrm{p}_{\text {crest }}}$ for the landslides induced by typhoon Morakot in Taiwan is distinct from that found for the three earthquakes. The typhoon caused uniform toe clustering (Fig. 3), with lower values of $R_{\text {prest }_{\text {cre }}}(\sim 0.5)$ in the aforementioned watersheds than those obtained in the same region for landslides induced by the Chi-Chi earthquake, even though these also cluster downslope. This observation, added to the results concerning the temporal variation of $R_{\mathrm{p}_{\text {crest }}}$ presented in Sect. 4.1, suggests that toe clustering is a signature of rainfall-induced landslides.

\section{Controls of clustering}

Pervasive crest clustering of co-seismic landslides within an earthquake epicentral area would signal the predominance of seismic controls over any other controls. By contrast, a noisy distribution of crest clustering could suggest that the location of landslides is controlled by highly variable local factors such as topographic slope, soil moisture, or soil depth.

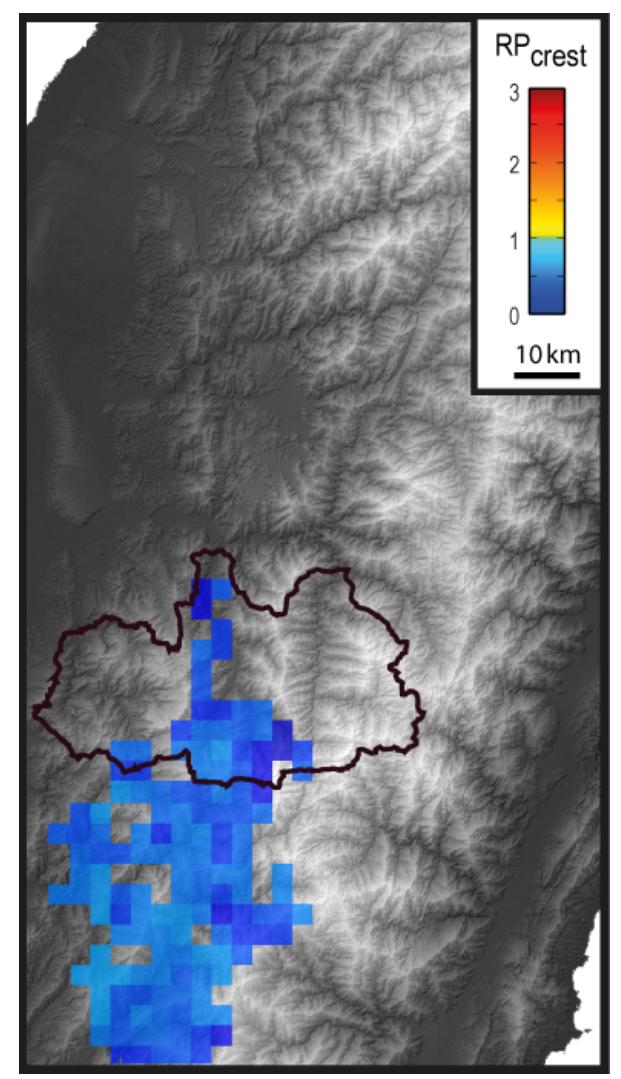

Figure $3 . R_{\text {prest }_{\text {crap }}}$ map associated with typhoon-Morakot-induced landslides in the southwestern part of the Chi-Chi epicentral area. Only toe clustering is observed. The black line delimits the three watersheds where $R_{\mathrm{p}_{\text {crest }}}$ is documented from 1996 to 2014 for rainfall- and Chi-Chi-induced landslides (Fig. 1).

The existence of coherent patterns of crest or toe clustering over hundreds of square kilometres suggests a large-scale control such as regional geological structures or geomorphic features.

\subsection{Seismic controls}

In our examples, crest clustering is not primarily explained by regional seismic parameters. Figure 4 shows $R_{\text {prest }}$ plotted against the median of peak ground velocity (PGV) (Fig. 4a) and pseudo-static acceleration at $1 \mathrm{~s}$ (PSA 1s) published on ShakeMap (Fig. 4b). For the Northridge and Wenchuan earthquakes, crest and toe clustering both occur over a wide range of PGV (1-100 $\left.\mathrm{cm} \mathrm{s}^{-1}\right)$ and PSA (0.1-1 g). In Taiwan, $R_{\mathrm{p}_{\text {crest }}}$ weakly increases with PGV and PSA 1s, but the spatial distribution of the patterns relative to the regional geological structure may cause misattribution. Indeed, as PGV and PSA strongly decrease towards the east, the strength of the geological units increases (see Sect. 5.3 and Fig. S12). Similar results are found for PGA and PSA 3s (Fig. S13). 


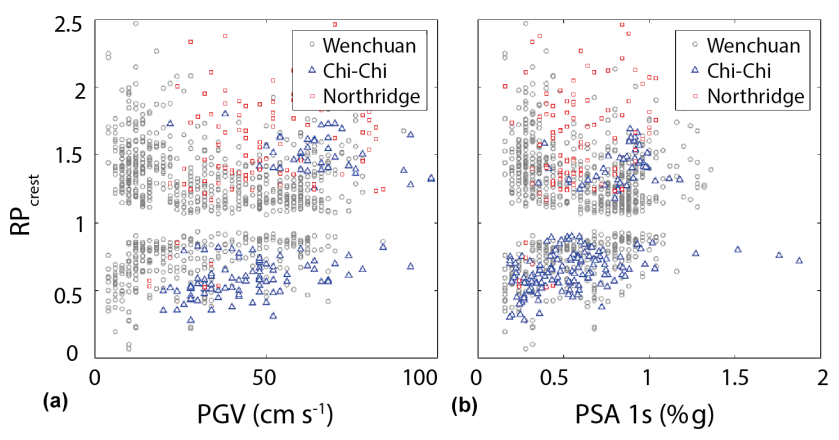

Figure 4. $R_{\mathrm{p}_{\text {crest }}}$ as a function of seismic features: (a) median peak ground velocity (PGV) $\left(\mathrm{cm} \mathrm{s}^{-1}\right)$ and (b) median pseudo-spectral acceleration at $1 \mathrm{~s}$ (PSA 1s) calculated in the Wenchuan, Northridge, and Chi-Chi epicentral areas. Regional seismic parameters do not seem to explain landslide position along hillslopes.

\subsection{Geomorphic controls}

Local hillslope geometry does not explain cluster location. Figure 5c shows $R_{\text {prest }_{\text {cr }}}$ plotted against the median of the ratio of the gradient of the upper and lower hillslope quarters. No correlation can be identified. Both hillslope local relief and aspect ratio also fail to segregate zones of crest clustering from zones of toe clustering (Fig. 5a-b), with the possible exception of the Chi-Chi case. There $R_{\text {prest }}$ seems to decrease as slopes become higher and steeper.

\subsection{Geological control on $R_{\text {prest }}$ distribution}

Maps of $R_{\text {prest }}$ projected on the main lithological units of the three epicentral areas are shown in Fig. S9. Meanwhile, the statistical distributions of $R_{\text {prest }}$ per lithology are reported in boxplots in Fig. 6. In the Chi-Chi case, crest clustering is principally observed in the western foothills comprised of poorly consolidated sandstones with interbedded marls and mudstones (Camanni et al., 2014; MOEA and Central Geological Survey, 2008) (Figs. 6b. and S9c). The higher-grade lithological units to the east are mainly affected by toe clustering. Hence, lithology seems to be a first-order control on the distribution patterns of $R_{\text {prest }_{\text {c }}}$.

However, in the Northridge and Wenchuan cases, the distribution of $R_{\text {pcrest }}$ is not correlated in a simple way with rock strength according to simple lithological classes (Fig. 6a-c). In the Wenchuan epicentral area, rocks with various deformation grades are observed, depending among other things on the major geological structures that intersect them. For instance, intensely deformed sandstones are found into the Wenchuan shear zone, while they are moderately deformed within the Songpan-Garzê units and relatively intact in the foothills (e.g. Robert, 2011). This geological diversity allows for a more detailed, ad hoc analysis of substrate controls on landslide location.

From our data, crest and toe clustering of co-seismic landslides seem to be concentrated along specific geological fea- tures. This is illustrated by the following observations from the Wenchuan epicentral area, which is large and geologically diverse.

In the Wenchuan shear zone, landslide toe clustering occurs along the Minjiang river valley (Fig. 7b). This river is entrained in the Wenchuan shear zone over more than $60 \mathrm{~km}$, where the deformation of rocks is very intense (e.g. Godard et al., 2010; Liu-Zeng et al., 2011). In this area, mostly Paleozoic rocks have several schistosities and intense foliation that strongly decrease their strength (Fig. 7 cross section AB). The deformation is particularly intense in this zone due to the presence of resistant granitic massifs on both sides of the fault zone (Robert, 2011). The most weakened material is downslope where the fault cuts the surface.

The central part of the foothills of the Longmen Shan is characterized by two large units: the so-called "upper unit" has large lithological contrasts over short distances $(\sim 10 \mathrm{~km})$ due to folding and thrusting, while the "lower unit" is more uniform (Fig. 7a-c cross section C-D). In the upper unit co-seismic landslides have a coherent toeclustering pattern, whereas the lower unit has a clear crestclustering pattern (Figs. 7a and S14b). A strong concentration of landslides is observed on lower slope segments along the Beichuan fault, especially up to the Jinhe and Mianyuan rivers branches (Figs. 7 and S14b). Around this fault, massive Permian dolomites top the cataclastic Triassic rocks, which crop out along the Tuojiang river, forcing failures downslope. In the area of Qiaping, between the Beichuan fault and the Pengguan massif and along the Mianyuan river, Silurian and Devonian sedimentary rock layers dip steeply and bear traces of strong deformation, including pervasive schistosity (Robert, 2011) (Fig. 7a-c cross section E-F). There, the downslope layers could be more susceptible to toppling onto the riverbed. The location of landslides is thus strongly controlled by the stratigraphy (weak rocks downslope topped by strong rock forming the crests), bedding dip, and the fault weakening zone.

In the foothills of the Longmen Shan, except the central part discussed above, crest clustering of landslides is clearly dominant. In the northeastern part, most of the landslides oversampled the crests of the large Tangwanzhai syncline (Figs. 7 and S17d). In this area, the presence of this large syncline strongly influences the morphology as the crests formed by sandstone and limestone strata are almost parallel to the Wenchuan fault system (Fig. 7a and c cross section G-H and Fig. S15 cross section I-J). Similar patterns are observed in the Sanjiang klippe and on both sides of the Tuojiang river in the Longmen Shan central zone (Figs. 7, S14a and S15 cross section $\mathrm{K}-\mathrm{L}$ ). These crests are made of stronger and more resistant rocks, implying the formation of steep slopes in the direction opposite to the dip of sedimentary layering. This slope asymmetry is marked by a strong curvature along the crests, a configuration that could favour the amplification of ground motion, promoting toppling or wedge failures. 

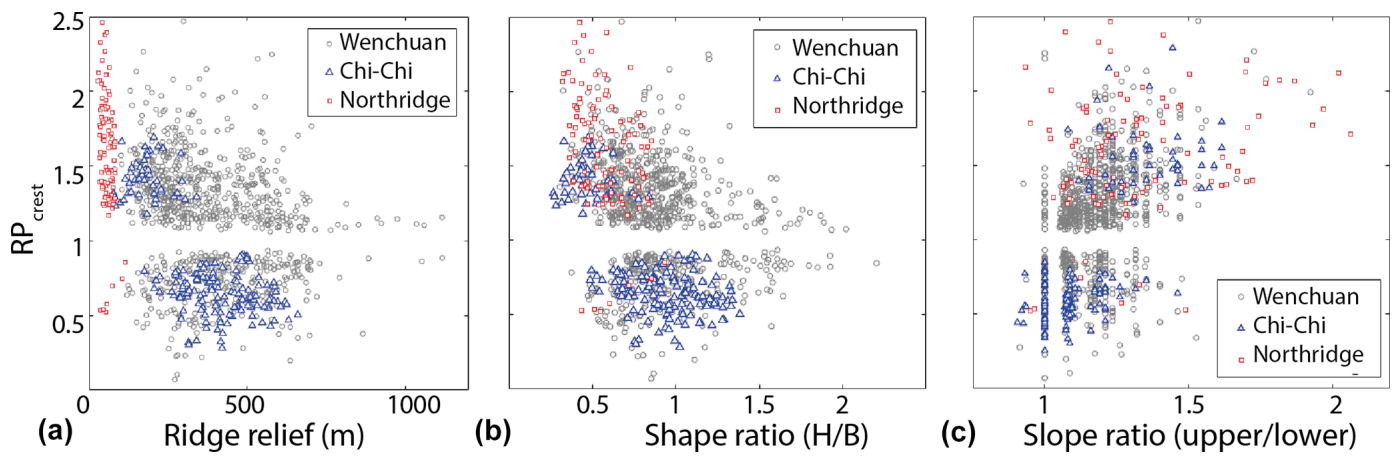

Figure 5. $R_{\mathrm{p}_{\text {crest }}}$ as a function of topographic features: (a) ridge relief, (b) hill shape ratio (H: ridge relief, B: half-width of the hill), and (c) upper over lower hillslope gradient ratio calculated in the Wenchuan, Northridge, and Chi-Chi epicentral areas.
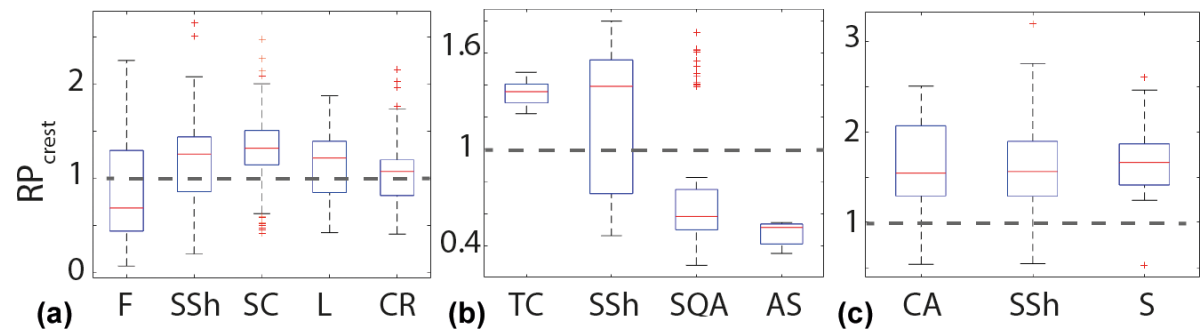

Figure 6. $R_{\mathrm{p}_{\text {crest }}}$ as a function of the lithologic groups of the (a) Wenchuan, (b) Chi-Chi, and (c) Northridge epicentral areas. F: flysch; SSh: mostly sandstones and shales; SC: mostly sandstones and conglomerates; L: mostly limestones; CR: crystalline rocks; TC: terrace deposits and conglomerates; SQA: shaly sandstones, quartzite, and argillite; AS: argillite and sandstones; CA: colluvium and alluvium; S: mostly sandstones.

Finally, in the earthquake-affected crystalline massifs of the Longmen Shan (Pengguan, Xuelang Bao, and Baoxing), crest clustering is also dominant, except along the Minjiang river (Fig. 7a).

Meanwhile, in the Chi-Chi epicentral area, crest clustering is observed in the foothills made of terrace deposits and alternating sandstone and shale strata (Fig. S7c). Toe clustering is found in the eastern part of the epicentral area with steep valleys, aligned major faults, cut shaly sandstones, and slightly metamorphosed argillite layers (Fig. S9c).

In the Northridge area, crest clustering is observed where interbedded conglomerate sandstones and shales form the crests of the northern part of the Santa Susanna Mountains (Harp and Jibson, 1996; Winterer and Durham, 1962) (Fig. S16). There, co-seismic landslides preferentially occurred on top of the scarp slopes. This configuration seems to be similar to that in the Tangwanzhai area of the Wenchuan earthquake (Fig. S17d). Crest clustering is also observed in the so-called badlands at the fringe of the Santa Clarita basin, which have formed in a homogeneous weak lithology (Fig. S9b).

In summary, three main types of geological effects were identified as major controls on landslide clustering: (a) rivers flowing along fault zones with structurally weakened rocks, (b) stratigraphic alternations of strong and weak units, and (c) the effect of bedding on the steepest hillslopes $\left(>26^{\circ}\right)$.

\section{Discussion and conclusion}

In this study we have systematically tested for a range of controls on the position of co-seismic landslides relative to the toe and the crest of hillslopes. Confirming previous studies (e.g. Densmore and Hovius, 2000; Meunier et al., 2008), we find that rain-triggered landslides occur preferentially at slope toes, likely due to high pore pressures associated with infiltration and fast downslope flow of groundwater in fractured rock mass, regolith, and colluvium during rainfall. The location of earthquake-triggered landslides is, on average, higher on hillslopes than rainfall-induced ones and displays coherent patterns of toe and crest clustering spread over the entire epicentral area. Where we have identified clear patterns of crest and toe clustering within the epicentral area of the Northridge, Chi-Chi, and Wenchuan earthquakes, these are due to a combination of seismic mechanisms and geological controls.

Toe clustering of seismically triggered landslides occurs mainly in areas where hillslope materials are heavily fractured and weathered, particularly in river valleys along major fault zones and more specifically near the fault where the deformation is the highest. The influence of fault zone weakening on slope stability has been documented in other contexts (e.g. Demir et al., 2013; Korup, 2004; Scheingross et al., 2013). In the absence of particular geological struc- 

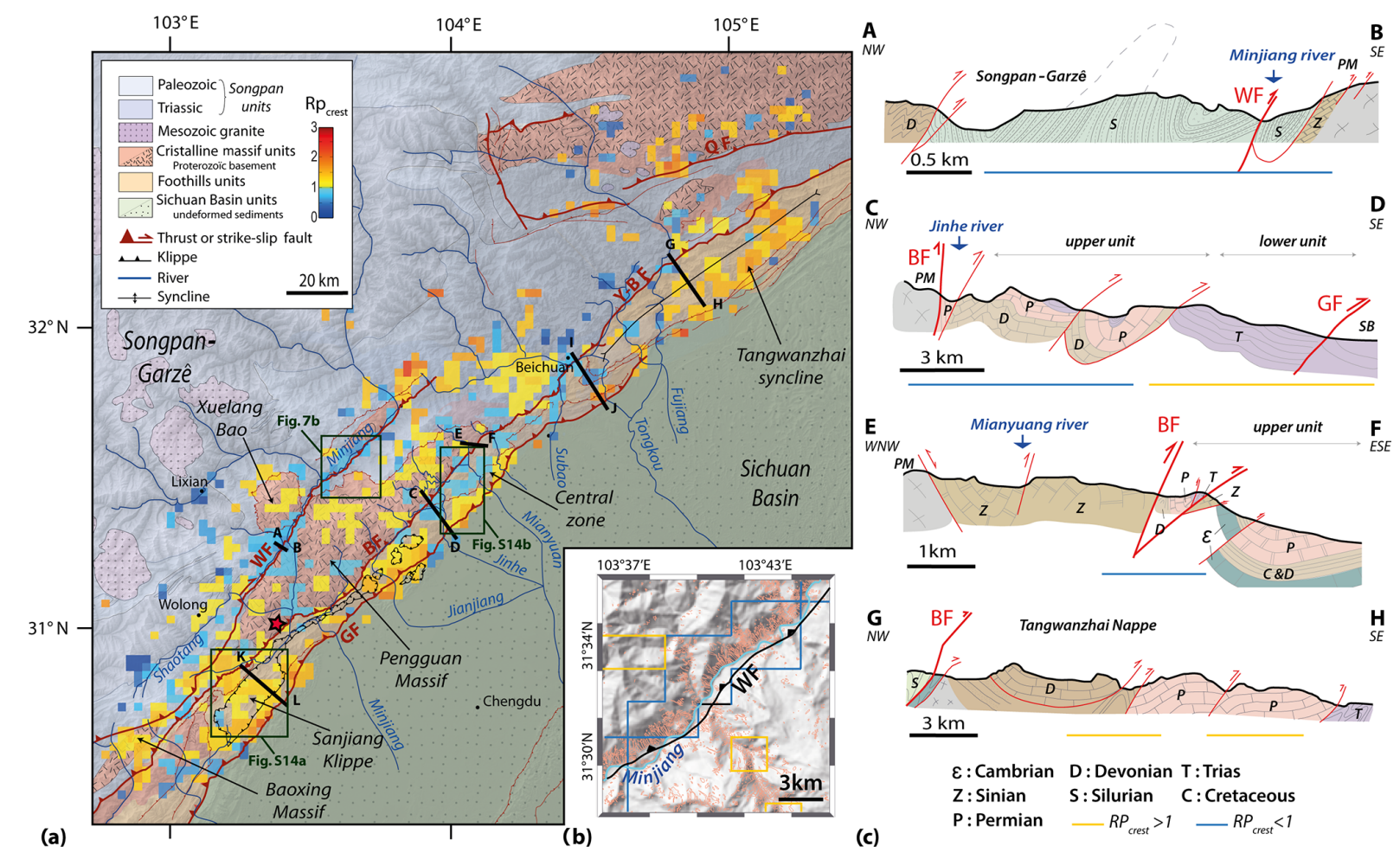

Figure 7. (a) Structural map of the Wenchuan earthquake epicentral area (after Robert, 2011) overlaid with the $R_{\mathrm{p}_{\text {crest }}}$ map. (b) Snapshot of the landslide map in a portion of the Wenchuan shear zone. Its location is reported in Fig. 7a. Polygons with red contours represent the co-seismic landslides mapped by Xu et al. (2014). The yellow and blue lines delimit zones of crest and toe clustering, respectively. (c) Cross sections of different structural units after Robert (2011). Cross sections I-J and K-L are presented in Fig. S15. Complementary snapshots of the landslide map are shown in Fig. S14. GF: Guanxian fault, BF: Beichuan fault, WF: Wenchuan fault, Y-B F: Yinxiu-Beichuan fault, QF: Qinling fault.

tures, toe clustering is also observed along trunk valleys in hard rock massifs where static stress can induce severe fracturing at the base of topographic ridges (Molnar, 2004) and where weak stratigraphic units crop out low in mountain landscapes. Therefore, toe clustering of co-seismic landslides appears to be explained at the first order by geological and structural controls. These controls add to any effects of possible downslope seismic amplification due to surface wave generation or directional effects (Pilz et al., 2018; Wasowski et al., 2013).

Crest clustering of co-seismic landslides is found primarily in areas without strong lithological contrasts, specific geological structures, or away from river trunk valleys. It is particularly well developed in regions underlain by sedimentary rocks, where ridge crests are defined by specific beds oriented parallel to the seismogenic faults. In these particular geological configurations, topographic amplification could control the landslide position. For example, in the Tangwanzhai syncline, the sharpest crests are oversampled by landslides (see the Supplement, "Topographic amplification", Fig. S17). Several authors have shown that ridge sharpness promotes topographic amplification (Maufroy et al., 2015; Rai et al., 2016). The landslide position would thus reflect the expression of strong ground motion in the uppermost part of the slope, which can be explained by complex interactions of various seismic waves with both topography and lithology. The focusing of waves on the edges of slopes may induce sufficient amplification of the ground motion to trigger slope failures (e.g. Kaiser et al., 2013; Stahl et al., 2014). Higher levels of amplification may be reached when the incoming wave is perpendicular to the ridge elongation (Massa et al., 2010) and thus increase the probability of failure. Moreover, some authors suggest that Rayleigh waves, generated at the toe of the hillslope and propagating toward the ridge crest, would produce an added inertial force on the sliding mass and increase the duration of ground motion, favouring upper slope failures (Jafarzadeh et al., 2015; Poursartip and Kallivokas, 2018).

We do not find clear explanations for the presence of some of the large crest- and toe-clustering patterns, such as in Wenchuan along the Subo River or east of Beichuan. Additional field observations in these areas may help to document these signals.

Our results reconsider the hypothesis of Meunier et al. (2008) since we show that the co-seismic landslide position along hillslopes is strongly modulated by geologi- 
cal features (stratigraphy and bedding) and structures (faults and folds). The ground motion intensity controls the landslide density (Meunier et al., 2007; Yuan et al., 2013) and seems to influence the distribution of the landslide size (Marc et al., 2016; Valagussa et al., 2019), but it seems to be a secondary control on their positions along hillslopes in geologically contrasting epicentral areas. Hazard scenarios for earthquake-induced landslides should not only consider lithology units but should also strive to consider stratigraphic and structural objects that can favour landsliding on specific hillslope sections.

Data availability. Landslide catalogs are available for download at https://www.sciencebase.gov/catalog/item/ 586d824ce4b0f5ce109fc9a6 (Tanyas et al., 2017).

Shake maps related to the study earthquakes are available for download at https://earthquake.usgs.gov/data/shakemap/ (U.S. Geological Survey, 2003).

Supplement. The supplement related to this article is available online at: https://doi.org/10.5194/esurf-7-829-2019-supplement.

Author contributions. CR developed the method, computed results, and prepared the paper. PM developed the method, computed results, and prepared the paper. AR contributed her expertise on geological structures in the Wenchuan earthquake area and prepared the paper. OM mapped the rainfall-triggered landslides in Taiwan and prepared the paper. $\mathrm{NH}$ participated in method development and preparation of the paper.

Competing interests. The authors declare that they have no conflict of interest.

Acknowledgements. We thank Manuel Pubellier for relevant discussions.

Review statement. This paper was edited by Xuanmei Fan and reviewed by two anonymous referees.

\section{References}

Allen, T. I. and Wald, D.: Topographic Slope as a Proxi for Seismic Site-Conditions (VS30) and Amplification Around the Globe, 2007.

Angelier, J., Lee, J. C., Chu, H. T., Hu, J. C., Lu, C. Y., Chan, Y. C., Tin-Jai, L., Font, Y., Deffontaines, B., and Yi-Ben, T.: Le séisme de Chichi (1999) et sa place dans l'orogène de Taiwan, Comptes Rendus de l'Academie de Sciences - Serie IIa: Sciences de la Terre et des Planetes, 333, 5-21, https://doi.org/10.1016/S12518050(01)01563-4, 2001.
Ashford, S. A., Sitar, N., Lysmer, J., and Deng, N.: Topographic effects on the seismic response of steep slopes, B. Seismol. Soc. Am., 87, 701-709, 1997.

Asimaki, D. and Mohammadi, K.: On the complexity of seismic waves trapped in irregular topographies, Soil Dyn. Earthq. Eng., 114, 424-437, https://doi.org/10.1016/j.soildyn.2018.07.020, 2018.

Boore, D. M.: The effect of simple topography on seismic waves: implications for the accelerations recorded at Pacoima Dam, San Fernando Valley, California, B. Seismol. Soc. Am., 63, 16031609, 1973.

Burjánek, J., Edwards, B., and Fäh, D.: Empirical evidence of local seismic effects at sites with pronounced topography: A systematic approach, Geophys. J. Int., 197, 608-619, https://doi.org/10.1093/gji/ggu014, 2014.

Camanni, G., Brown, D., Alvarez-Marron, J., Wu, Y.-M., and Chen, H.-A.: The Shuilikeng fault in the central Taiwan mountain belt J. Geol. Soc., 171, 117-130, https://doi.org/10.1144/jgs2013014, 2014.

Chávez-Garcia, F. J., Sánchez, L. R., and Hatzfeld, D.: Topographic site effects and HVSR. A comparison between observations and theory, B. Seismol. Soc. Am., 86, 1559-1573, 1996.

Chien, F. C. and Kuo, H. C.: On the extreme rainfall of Typhoon Morakot (2009), J. Geophys. Res.-Atmos., 116, D05104, https://doi.org/10.1029/2010JD015092, 2011.

De Michele, M., Raucoules, D., De Sigoyer, J., Pubellier, M., and Chamot-Rooke, N.: Three-dimensional surface displacement of the 2008 May 12 Sichuan earthquake (China) derived from Synthetic Aperture Radar: Evidence for rupture on a blind thrust, Geophys. J. Int., 183, 1097-1103, https://doi.org/10.1111/j.1365-246X.2010.04807.x, 2010.

Demir, G., Aytekin, M., Akgün, A., Ikizler, S. B., and Tatar, O.: A comparison of landslide susceptibility mapping of the eastern part of the North Anatolian Fault Zone (Turkey) by likelihoodfrequency ratio and analytic hierarchy process methods, Nat. Hazards, 65, 1481-1506, 2013.

Densmore, A. L. and Hovius, N.: Topographic fingerprints of bedrock landslides, Geology, 28, 371-374, 2000.

Domej, G., Bourdeau, C., Lenti, L., Martino, S. and Pluta, K.: Mean landslide geometries inferred from globla database, 94 Italian Journal of Engineering Geology and Environment, 2, 87-107, https://doi.org/10.4408/IJEGE.2017-02.O-05, 2017.

Durante, F., Di Giulio, G., Tallini, M., Milana, G., and Macerola, L.: A multidisciplinary approach to the seismic characterization of a mountain top (Monteluco, central Italy), Phys. Chem. Earth, 98, 119-135, https://doi.org/10.1016/j.pce.2016.10.015, 2017.

Gallipoli, M. R., Bianca, M., Mucciarelli, M., Parolai, S., and Picozzi, M.: Topographic versus stratigraphic amplification: Mismatch between code provisions and observations during the L'Aquila (Italy, 2009) sequence, B. Earthq. Eng., 11, 1325-1336, https://doi.org/10.1007/s10518-013-9446-3, 2013.

Geli, L., Bard, P.-Y., and Jullien, B.: The effect of topography on earthquake ground motion: a review and new results, B. Seismol. Soc. Am., 78, 42-63, 1988.

Glinsky, N. and Bertrand, E.: Numerical investigation of topographical site effects: parametric study on simplified geometries and impact of the inner geological structure, in Proceedings of 16WCEE, 16th World Conference on Earthquake Engineering, 2017. 
Godard, V., Lavé, J., Carcaillet, J., Cattin, R., Bourlès, D., and Zhu, J.: Spatial distribution of denudation in Eastern Tibet and regressive erosion of plateau margins, Tectonophysics, 491, 253-274, https://doi.org/10.1016/j.tecto.2009.10.026, 2010.

Gorum, T., Fan, X., Van Westen, C. J., Huang, R. Q., $\mathrm{Xu}$, Q., Tang, C., and Wang, G.: Distribution pattern of earthquake-induced landslides triggered by the 12 May 2008 Wenchuan earthquake, Geomorphology, 133, 152-167, https://doi.org/10.1016/j.geomorph.2010.12.030, 2011.

Harp, E. L. and Jibson, R. W.: Landslides triggered by the 1994 Northridge, California, earthquake, B. Seismol. Soc. Am. 86, S319-S332, 1996.

Hartzell, S., Meremonte, M., Ramirez-Guzmán, L., and McNamara, D.: Ground motion in the presence of complex topography: Earthquake and ambient noise sources, B. Seismol. Soc. Am., 104, 451-466, 2014.

Havenith, H. B., Vanini, M., Jongmans, D., and Faccioli, E.: Initiation of earthquake-induced slope failure: Influence of topographical and other site specific amplification effects, J. Seismol., 7, 397-412, https://doi.org/10.1023/A:1024534105559, 2003.

Jafarzadeh, F., Shahrabi, M. M., and Jahromi, H. F.: On the role of topographic amplification in seismic slope instabilities, Journal of Rock Mechanics and Geotechnical Engineering, 7, 163-170, https://doi.org/10.1016/j.jrmge.2015.02.009, 2015.

Kaiser, A., Holden, C. and Massey, C.: Determination of site amplification, polarization and topographic effects in the seismic response of the Port Hills following the 2011 Christchurch earthquake, NZSEE Conference, Wellington, New Zealand, 1-8, 2013

Keefer, D. K.: Landslides caused by Earthquakes, Geol. Soc. Am., 95, 406-421, 1984.

Korup, O.: Geomorphic implications of fault zone weakening: Slope instability along the alpine fault, South Westland to Fiordland, New Zeal. J. Geol. Geop., 47, 257-267, https://doi.org/10.1080/00288306.2004.9515052, 2004.

Liao, H. and Lee, C. T.: Landsides triggered by the Chi-Chi Earthquake, in: Proceedings of the 21st Asian Conference on Remote Sensing, vol. 1 and 2, 383-388, 2000.

Lin, C. W., Chang, W. S., Liu, S. H., Tsai, T. T., Lee, S. P., Tsang, Y. C., Shieh, C. L., and Tseng, C. M.: Landslides triggered by the 7 August 2009 Typhoon Morakot in southern Taiwan, Eng. Geol., 123, 3-12, https://doi.org/10.1016/j.enggeo.2011.06.007, 2011.

Liu-Zeng, J., Wen, L., Oskin, M., and Zeng, L.: Focused modern denudation of the Longmen Shan margin, eastern Tibetan Plateau, Geochem. Geophy. Geosy., 12, 1-21, https://doi.org/10.1029/2011GC003652, 2011.

Lovati, S., Bakavoli, M. K. H., Massa, M., Ferretti, G., Pacor, F., Paolucci, R., Haghshenas, E., and Kamalian, M.: Estimation of topographical effects at Narni ridge (Central Italy): Comparisons between experimental results and numerical modelling, B. Earthq. Eng., 9, 1987-2005, https://doi.org/10.1007/s10518011-9315-x, 2011.

Marc, O., Hovius, N., Meunier, P., Uchida, T., and Hayashi, S.: Transient changes of landslide rates after earthquakes, Geology, 43, 883-886, https://doi.org/10.1130/G36961.1, 2015.

Marc, O., Hovius, N., Meunier, P., Gorum, T., and Uchida, T.: A seismologically consistent expression for the total area and volume of earthquake-triggered landsliding, J. Geophys. Res.-Earth, 121, 640-663, https://doi.org/10.1002/2015JF003732, 2016.
Marc, O., Meunier, P., and Hovius, N.: Prediction of the area affected by earthquake-induced landsliding based on seismological parameters, Nat. Hazards Earth Syst. Sci., 17, 1159-1175, https://doi.org/10.5194/nhess-17-1159-2017, 2017.

Marc, O., Stumpf, A., Malet, J.-P., Gosset, M., Uchida, T., and Chiang, S.-H.: Initial insights from a global database of rainfallinduced landslide inventories: the weak influence of slope and strong influence of total storm rainfall, Earth Surf. Dynam., 6, 903-922, https://doi.org/10.5194/esurf-6-903-2018, 2018.

Massa, M., Lovati, S., D’Alema, E., Ferretti, G., and Bakavoli, M. K. H.: An experimental approach for estimating seismic amplification effects at the top of a ridge, and the implication for groundmotion predictions: The case of Narni, Central Italy, B. Seismol. Soc. Am., 100, 3020-3034, https://doi.org/10.1785/0120090382, 2010.

Massa, M., Barani, S., and Lovati, S.: Overview of topographic effects based on experimental observations: meaning, causes and possible interpretations, Geophys. J. Int., 197, 1537-1550, 2014.

Massey, C., Della Pasqua, F., Holden, C., Kaiser, A., Richards, L., Wartman, J., McSaveney, M. J., Archibald, G., Yetton, M., and Janku, L.: Rock slope response to strong earthquake shaking, Landslides, 14, 249-268, https://doi.org/10.1007/s10346016-0684-8, 2017.

Maufroy, E., Cruz-Atienza, V. M., Cotton, F., and Gaffet, S.: Frequency-Scaled Curvature as a Proxy for Topographic SiteEffect Amplification and Ground-Motion Variability, B. Seismol. Soc. Am., 105, 354-367, 2015.

Meunier, P., Hovius, N., and Haines, A. J.: Regional patterns of earthquake-triggered landslides and their relation to ground motion, Geophys. Res. Lett., 34, L20408, https://doi.org/10.1029/2007GL031337, 2007.

Meunier, P., Hovius, N., and Haines, J. A.: Topographic site effects and the location of earthquake induced landslides, Earth Planet. Sc. Lett., 275, 221-232, https://doi.org/10.1016/j.epsl.2008.07.020, 2008.

MOEA and Central Geological Survey: Geological Map Database, available at: http://gis.moeacgs.gov.tw/gwh/gsb97-1/sys8/index. cfm (last access: 12 December 2017), 2008.

Molnar, P.: Interactions among topographically induced elastic stress, static fatigue, and valley incision, J. Geophys. Res.-Earth, 109, F02010, https://doi.org/10.1029/2003JF000097, 2004.

Ohtsuki, A. and Harumi, K.: Effect of topography and subsurface inhomogeneities on seismic SV waves, Earthq. Eng. Struct. D., 11, 441-462, https://doi.org/10.1002/eqe.4290110402, 1983.

Paolucci, R.: Amplification of earthquake ground motion by steep topographic irregularities, Earthq. Eng. Struct. D., 31, 18311853, 2002.

Parker, R. N., Densmore, A. L., Rosser, N. J., de Michele, M., Li, Y., Huang, R., Whadcoat, S., and Petley, D. N.: Mass wasting triggered by the 2008 Wenchuan earthquake is greater than orogenic growth, Nat. Geosci., 4, 449, https://doi.org/10.1038/ngeo1154, 2011.

Pedersen, H. A., LeBrun, B., Hatzfeld, D., Campillo, M., and Bard, P. Y.: Ground motion amplitude across ridges, B. Seismol. Soc. Am., 84, 1786-1800, 1994.

Pilz, M., Parolai, S., Petrovic, B., Silacheva, N., Abakanov, T., Orunbaev, S., and Moldobekov, B.: Basin-edge generated Rayleigh waves in the almaty basin and corresponding conse- 
quences for ground motion amplification, Geophys. J. Int., 213, 301-316, https://doi.org/10.1093/gji/ggx555, 2018.

Poursartip, B. and Kallivokas, L. F.: Model dimensionality effects on the amplification of seismic waves, Soil Dyn. Earthq. Eng., 113, 572-592, https://doi.org/10.1016/j.soildyn.2018.06.012, 2018 .

Poursartip, B., Fathi, A., and Kallivokas, L. F.: Seismic wave amplification by topographic features: A parametric study, Soil Dyn. Earthq. Eng., 92, 503-527, https://doi.org/10.1016/j.soildyn.2016.10.031, 2017.

Rai, M., Rodriguez-Marek, A., and Yong, A.: An Empirical Model to Predict Topographic Effects in Strong Ground Motion Using California Small-to Medium-Magnitude Earthquake Database, Earthquake Spectra, 32, 1033-1054, 2016.

Robert, A.: Déformation polyphasée et importance de l'héritage structural dans les Longmen Shan (Sichuan, Chine) Apports d'une approche couplée entre géophysique et géologie, ENS Paris, 2011.

Rodríguez, C. E., Bommer, J. J., and Chandler, R. J.: Earthquakeinduced landslides: 1980-1997, Soil Dyn. Earthq. Eng., 18, 325346, https://doi.org/10.1016/S0267-7261(99)00012-3, 1999.

Scheingross, J. S., Minchew, B. M., Mackey, B. H., Simons, M., Lamb, M. P., and Hensley, S.: Fault-zone controls on the spatial distribution of slow-moving landslides, B. Geol. Soc. Am., 125, 473-489, https://doi.org/10.1130/B30719.1, 2013.

Sepúlveda, S. A., Serey, A., Lara, M., Pavez, A., and Rebolledo, S.: Landslides induced by the April 2007 Aysén Fjord earthquake, Chilean Patagonia, Landslides, 7, 483-492, https://doi.org/10.1007/s10346-010-0203-2, 2010.

Somerville, P., Saikia, C., Wald, D., and Graves, R.: Implications of the Northridge earthquake for strong ground motions from thrust faults, B. Seismol. Soc. Am., 86, 115-125, 1996.

Stahl, T., Bilderback, E. L., Quigley, M. C., Nobes, D. C., and Massey, C. I.: Coseismic landsliding during the Mw7.1 Darfield (Canterbury) earthquake: Implications for paleoseismic studies of landslides, Geomorphology, 214, 114-127, https://doi.org/10.1016/j.geomorph.2014.03.020, 2014.

Jennings, C. W. and Strand, R. G.: Geologic Map of California, Los Angeles Sheet, San Francisco, CA, 1969.

Tanyaş, H., Van Westen, C. J., Allstadt, K. E., Jessee, M. A. N., Görüm, T., Jibson, R. W., Godt, J. W., Sato, H. P., Schmitt, R. G., Marc, O., and Hovius, N.: Presentation and Analysis of a Worldwide Database of Earthquake-Induced Landslide Inventories, J. Geophys. Res.Earth, 122, 1991-2015, https://doi.org/10.1002/2017JF004236, 2017 (data available at: https://www.sciencebase.gov/catalog/ item/586d824ce4b0f5ce109fc9a6, last access: 15 June 2018).

Tong, X., Sandwell, D. T., and Fialko, Y.: Coseismic slip model of the 2008 Wenchuan earthquake derived from joint inversion of interferometric synthetic aperture radar, GPS, and field data, J. Geophys. Res., 115, B04314, https://doi.org/10.1029/2009JB006625, 2010.
Tsai, Y. B. and Huang, M. W.: Strong ground motion characteristics of the chichi, Taiwan, earthquake of September 21, 1999, Institute of Geophysics, National Central University, 2000.

Tseng, C.-M., Chen, Y.-R., and Wu, S.-M.: Scale and spatial distribution assessment of rainfall-induced landslides in a catchment with mountain roads, Nat. Hazards Earth Syst. Sci., 18, 687-708, https://doi.org/10.5194/nhess-18-687-2018, 2018.

U.S. Geological Survey: Search Earthquake Catalog, available at: https://earthquake.usgs.gov/earthquakes/search/ (last access: 30 January 2018), 2003.

U.S. Geological Survey: Earthquake hazard program: ShakeMap, available at: https://earthquake.usgs.gov/data/shakemap/, last access: 1 January 2018 a.

U.S. Geological Survey: USGS Geoscience Data Catalog: landslides, available at: https://geo-nsdi.er.usgs.gov/catalog/ combine.php?term=2-639\&with $=2-700$, last access: 1 January 2018 b.

Valagussa, A., Marc, O., Frattini, P., and Crosta, G. B.: Seismic and geologic controls on earthquake-induced landslide size, Earth Planet. Sc. Lett., 506, 268-281, 2019.

Wasowski, J., Gaudio, V. Del, Casarano, D., Lollino, P., and Muscillo, S.: Local Scale Seismic Landslide Susceptibility Assessment Based on Historic Earthquake Records Combined with Accelerometer Monitoring and Ambient Noise Data, in: Earthquake-Induced Landslides, edited by: Ugai, K., Yagi, H., and Wakai, A., Springer Berlin Heidelberg, Berlin, Heidelberg, 11-20, 2013.

Weissel, J. K. and Stark, C. P: Landslides triggered by the 1999 Mw7. 6 Chi Chi earthquake in Taiwan and their relationship to topography, in: Geoscience and Remote Sensing Symposium, 2, 759-761, 2001.

Wen, Z., Xie, J., Gao, M., Hu, Y., and Chau, K. T.: Nearsource strong ground motion characteristics of the 2008 Wenchuan earthquake, B. Seismol. Soc. Am., 100, 2425-2439, https://doi.org/10.1785/0120090266, 2010.

Winterer, E. L. and Durham, D. L.: Geology of the southeastern Ventura Basin, Los Angeles County, California, 1962.

$\mathrm{Xu}, \mathrm{C} ., \mathrm{Xu}, \mathrm{X}$. , Yao, X., and Dai, F.: Three (nearly) complete inventories of landslides triggered by the May 12, 2008 Wenchuan Mw 7.9 earthquake of China and their spatial distribution statistical analysis, Landslides, 11, 441-461, https://doi.org/10.1007/s10346-013-0404-6, 2014.

Yerkes, R. F., Campbell, R. H., Alvarez, R. M., and Bovard, K. R.: Preliminary geologic map of the Los Angeles $30^{\prime} \times 60^{\prime}$ Quadrangle, southern California, US Geological Survey Open File Report, 1019, 2005.

Yuan, R. M., Deng, Q. H., Cunningham, D., Xu, C., Xu, X. W., and Chang, C. P.: Density distribution of landslides triggered by the 2008 Wenchuan earthquake and their relationships to peak ground acceleration, B. Seismol. Soc. Am., 103, 2344-2355, https://doi.org/10.1785/0120110233, 2013. 